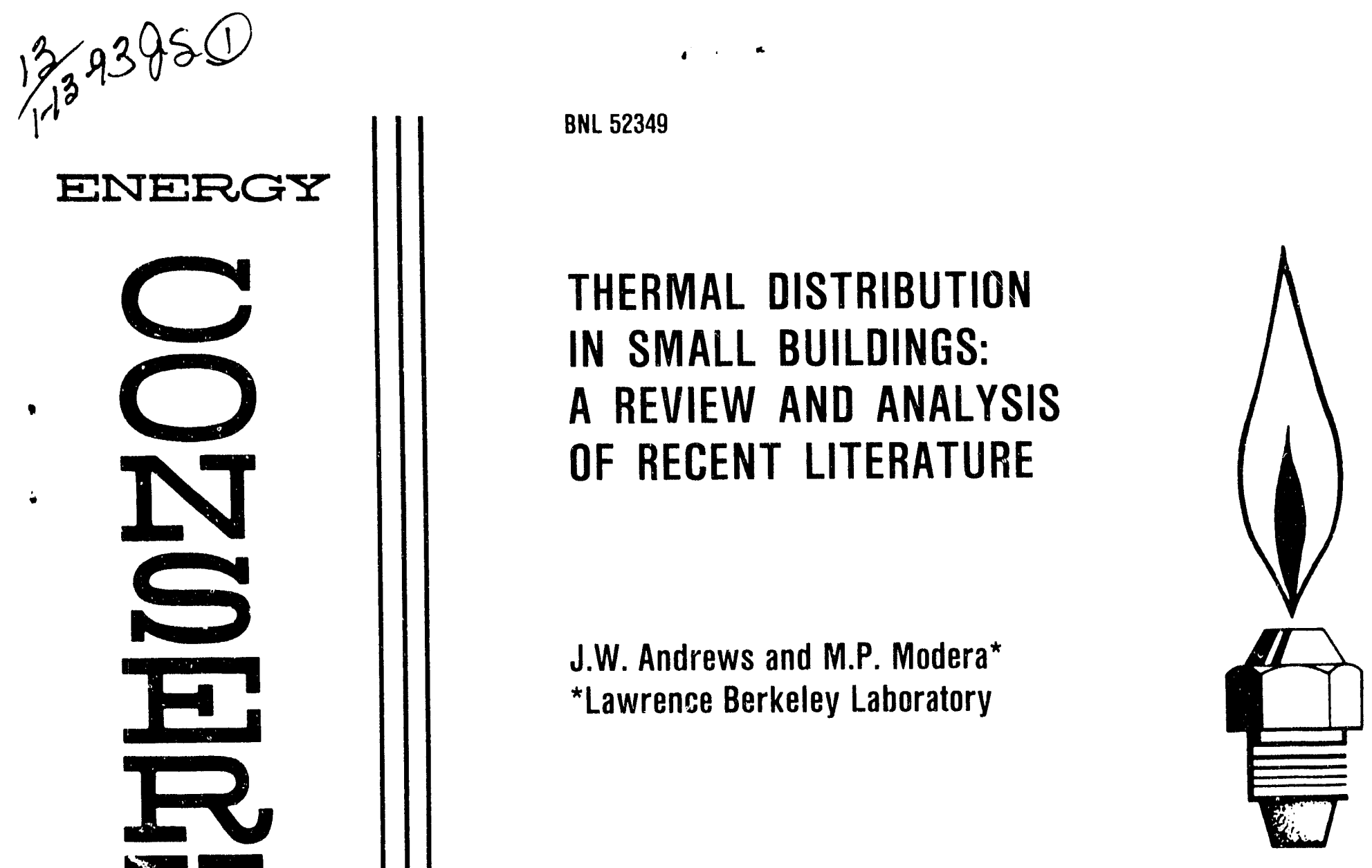

September 1992

Work Supported by the

BUILDING EQUIPMENT DIVISION

OFFICE OF BUILDING TECHNOLOGIES

UNITED STATES DEPARTMENT OF ENERGY

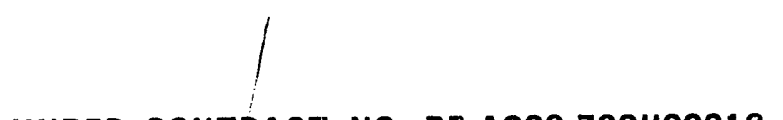

UNDER CONTRACT NO. DE-AC02-76CH00016 WITH THE

U.S. DEPARTMENT OF ENERGY 


\title{
THERMAL DISTRIBUTION IN SMALL BUILDINGS: A REVIEW AND ANALYSIS OF RECENT LITERATURE
}

\author{
September 1992
}

J.W. Andrews and M.P. Modera*

"Lawrence Berkeley Laboratory

Work Supported by the

BUILDING EQUIPMENT DIVISION

OFFICE OF BUILDING TECHNOLOGIES

UNITED STATES DEPARTMENT OF ENERGY

ENERGY EFFICIENCY AND CONSERVATION DIVISION

DEPARTMENT OF APPLIED SCIENCE

BROOKHAVEN NATIONAL LABORATORY

ASSOCIATED UWIVERSITIES, INC.

UPTON. LONG ISLAND, NEW YORK 11973

UNDER CONTRACT NO. DE-ACO2-76CHOOO16 WITH THE

UNITED STATES DEPARTMENT OF ENERGY 


\section{DISCLAIMER}

This report was prepared as an account of work sponsored by an agency of the United States Government. Neither the United States Government nor any agency thereof nor any of their employees, nor any of their contractors, subcontractors, or their employees, makes any warranty, express or implied, or assumes any legal liability or responsibility for the accuracy, completeness, or usefulness of any information. apparatus, product, or process disclosed, or represents that its use would not infringe privately owned rights. Reference herein to any specific commercial product, process. or service by trade name, trademark, manufacturer, or otherwise, does not necessarily constitute or imply its endorsement, recommendation, or favoring by the United States Government or any agency, contractor or subcontractor thereof. The views and opinions of authors expressed herein do not necessarily state or reflect those of the United States Government or any agency, contractor or subcontractor thereof.

Printed in the United States of America

Available from

National Technical Information Service

U.S. Department of Commerce

5285 Port Royal Road

Springfield, VA 22161

NTIS price codes:

Printed Copy: A03; Microfiche Copy: A01 
TABLE OF CONTENTS

Page

ABSTRACT

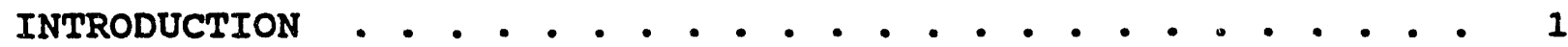

QUANTIFICATION OF DUCT LOSSES . . . . . . . . . . . . . . . 2

Fan-Induced Infiltration . . . . . . . . . . . 2

Duct Leakage . . . . . . . . . . . . . . . 5

Duct Losses Via Conduction . . . . . . . . . . . . 11

Overall Duct-Loss Measurements . . . . . . . . . 13

The Bottom Line . . . . . . . . . . . . . . 16

References . . . . . . . . . . . . . . . 12

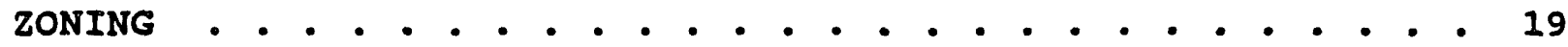

Predicted Energy Savings . . . . . . . . . . . . 19

Zoning Strategies . . . . . . . . . . . . . 20

Issues Related to zoning . . . . . . . . . . . . 22

Experimental Results--Setback . . . . . . . . 23

Summary of Predicted and Experimental

Results--Night Setback . . . . . . . . . . . . . 24

Experimental Results--Zoning . . . . . . . . . 25

Significance of Findings . . . . . . . . . . . . 28

References . . . . . . . . . . . . . . . . 30 
This report reviews and analyzes recent technical literature on two subjects relating to thermal distribution in small buildings: energy losses in ductwork and the energy consequences of zone control. Energy losses in ductwork stem from three factors: fan-induced infiltration, duct leakage, and conductive heat losses through duct walls. The first two mechanisms are intertwined, and together account for about half of all duct losses. Ducted forced-air distribution systems are found, on average, to be 60\%-70\% efficienct. Zone control, that is, the ability to operate different zones of a building at different temperatures, is potentially an energy-conserving strategy, but field results suggest that the energy savings are far from automatic. 
This report reviews and analyzes recent literature dealing with two aspects of thermal distribution in small buildings. The first of these is energy losses due to ductwork in forced-air distribution systems. Because architects and builders have tended to think of a small building as a shell into which a heating and cooling plant is installed, the role of the duct system in the building's overail energy budget has often been overlooked. Recently, experimental evidence from several regions of the United States has supported the idea that energy losses due to ductwork are large--comparable, in fact, to the energy losses in furnaces and boilers 20 years ago. Duct losses, however, are a more complex issue than equipment losses for two main reasons. First, ducts are intimately connected not only with the equipment but with the envelope as well. While it is a workable approximation to isolate a furnace or boiler from the rest of the building, with standardized assumptions concerning interactions such as combustion air sourcing and jacket losses, with ducts the interactions are both more numerous and of greater magnitude. Second, unlike furnaces, boilers, heat pumps, and air conditioners, which exist in a few hundred standardized models, duct systems are usually one-ofa-kind. The task of characterizing duct systems thus is more complicated than the similar task for heating or cooling equipment. Nevertheless, we believe that such characterization is essential if the building industry is to move toward a solution of the duct-loss problem. We make an analogy with space-conditioning equipment, for which figures of merit such as Annual Fuel Utilization Efficiency (AFUE) and Seasonal Energy Efficiency Ratio (SEER) have provided a basis both for competitive marketing of efficient equipment and for standards mandating such equipment. The fact that the task for thermal distribution is likely to be more difficult than the analogous task for equipment should not detract from a recognition that it needs to be done. This analysis is intended to provide input to the development of such a figure of merit.

Zone control has often been suggested as a means for energy conservation in small buildings. Zoning is relatively easy to do in new houses with hydronic or electric baseboard systems, but is more problematic in new housing with forced-air distribution systems and in most existing housing with the exception of that using electric baseboard. When zoning is attempted with forced-air distribution, the energy impact i- not always what the designer intended. The second major section in this report reviews recent field work in this area. 


\section{QUANTIFICATION OF DUCT LOSSES}

Duct losses can be categorized as stemming from three sources: duct leakage to an unconditioned space or to the outside; thermal losses via conduction through duct walls; and system impacts on whole-house infiltration rates. This discussion will attempt to draw together the literature on the subject, to determine whether the results from different researchers are in essential agreement, or whether there are significant areas of disagreement. As with any compendium of information from different sources, it is necessary to account for the possibility of differences in method or interpretation between them. Despite this caveat, we will persist in our attempt to determine whether a unified view emerges from the sources.

one additional remark needs to be made. In this analysis, we seek to quantify the losses occurring in ducts located in attics, crawlspaces, or other unconditioned spaces. Iosses in basement ducts are likely somewhat less; we treat these as a separate case.

\section{Fan-Induced Infiltration}

The last of the three abovementioned effects has had perhaps the greatest attention from researchers, and so we will consider it first. The results are usually presented in terms of the effect that the distribution fan has on the whole-house air infiltration rate. This is sometimes given as a comparison of infiltration fan-off vs. fan-on, or as a comparison between groups of otherwise comparable houses, one group having forced-air distribution systems and the other having electric baseboard. A summary of the first type of result is given in Table 1 .

An alternative measure of the infiltration impact of ductwork is to compare a population of buildings having ducts with a population of comparable buildings that have electric baseboard heating. In these cases, the average air change rate of the ducted systems is given over all times, including when the fan is on and when the fan is off. Thus, it is expected that the difference between the two cases will be less than in the above comparisons, since fan-off time is averaged in with fan-on time. Results of this type are given in Table 2 .

It should be noted that in all three studies cited in Table 2 , the air-change rate was measured by the perfluorocarbon tracer (PFT) method. This method is known to underestimate average ventilation rates, for the reason that the PFT method measures the inverse of the ventilation rate, and averaging the inverse of a variable quantity results in a low estimate of the average of the quantity itself. Sherman (1989) estimates a seasonal underprediction in the range 20-30\%. 


\begin{tabular}{|c|c|c|c|c|}
\hline \multirow[t]{2}{*}{ Reference } & \multirow[t]{2}{*}{$\begin{array}{l}\text { Number of } \\
\text { Houses }\end{array}$} & \multirow[t]{2}{*}{ Location } & \multicolumn{2}{|c|}{$\begin{array}{l}\text { Infiltration } \\
\text { Rate } \\
\text { (Air changes } / \mathrm{h} \text { ) }\end{array}$} \\
\hline & & & Fan off & Fan on \\
\hline Gammage et al. 1984 & 31 & TN & 0.44 & 0.78 \\
\hline Matthews st al. 1990 & 39 & $\begin{array}{c}\text { Tennessee } \\
\text { Valley }\end{array}$ & 0.56 & 0.90 \\
\hline Cummings et al. 1991 & 160 & FL & 0.28 & 0.91 \\
\hline Modera et al. 1991 & 31 & $\mathrm{CA}$ & 0.24 & $\begin{array}{r}0.69 \\
-\end{array}$ \\
\hline Mean of 4 Projects & & & 0.38 & 0.82 \\
\hline
\end{tabular}

Table 2. Infiltration Impact of Distribution Fan operation Forced Air vs. Non-Ducted Comparison

\begin{tabular}{|c|c|c|c|c|}
\hline \multirow{3}{*}{$\begin{array}{l}\text { Reference } \\
\text { Riley et al. } 1986\end{array}$} & \multirow{3}{*}{$\begin{array}{l}\text { Number of } \\
\text { Houses } \\
300\end{array}$} & \multirow{3}{*}{$\begin{array}{l}\text { Location } \\
\text { (States) } \\
\text { Canada } \\
\text { R-2000 } \\
\text { Control }\end{array}$} & \multicolumn{2}{|c|}{$\begin{array}{l}\text { Infiltration } \\
\text { Rate (Air } \\
\text { changes } / \mathrm{h})\end{array}$} \\
\hline & & & $\begin{array}{l}\text { Non- } \\
\text { Ducted }\end{array}$ & $\begin{array}{l}\text { Forced } \\
\text { Air }\end{array}$ \\
\hline & & & $\begin{array}{l}0.32 \\
0.28\end{array}$ & $\begin{array}{l}0.39 \\
0.38\end{array}$ \\
\hline Parker 1989 & 90 & $\begin{array}{l}\text { Pacific } \\
\text { Northwest }\end{array}$ & 0.23 & 0.41 \\
\hline Palmiter et al. 1991 & 492 & $\begin{array}{l}\text { Pacific } \\
\text { Northwest }\end{array}$ & 0.27 & 0.39 \\
\hline
\end{tabular}


The average increase in infiltration rates measured in the three studies of Table 2 is 0.133 air changes per hour ( $A C H)$. If we increase this by 208 to allow for the PFT underestimation effect, we obtain a revised estimate of $0.16 \mathrm{ACH}$.

Comparison of this estimate with the results from Table 1 presents difficulties, but as a baseline one might assume that, if the fan is operating for the $23 \%$ of the time that is assumed in the Annual Fuel Utilization Efficiency (AFUE) calculations, the difference in air infiltration between ducted and non-ducted systems would be at least $23 \%$ of the fan-on vs. fan-off difference cited in Table 1, that is $0.23 \times(0.82-0.38)$, or $0.10 \mathrm{ACH}$. In addition, one would expect a difference between the fan-off $A C H$ and the non-ducted $\mathrm{ACH}$. If the ductwork constitutes about $14 \%$ of the effective leakage area of the house (see below), one would expect it to add at least $14 \%$ of the non-ducted $\mathrm{ACH}$. (It may add more than this because ductwork is usually located either near the ground or near the top portion of the house, where the driving forces are greater than average.) Multiplying 0.27 , the average of the non-ducte" $\mathrm{ACH}$ for the projects in Table 2, by the factor 0.14 yields $0.04 \mathrm{ACH}$. Adding this to the $0.10 \mathrm{ACH}$ increment due to fan operation then yields a predicted overall impact of $0.14 \mathrm{ACH}$ due to the ductwork.

Thus, from the fan-off/fan-on studies (Table 1), we derive an estimate of $0.14 \mathrm{ACH}$ as the average incremental air infiltration rate due to ductwork, while in the ducted/non-ducted studies (Table 2), we derive an estimate of $0.16 \mathrm{ACH}$. In what follows, we will take the average of these two values, or $0.15 \mathrm{ACH}$, as our combined estimate of the impact of ductwork on air infiltration.

The energy-use impact of an incremental $0.15 \mathrm{ACH}$ over the heating season will be estimated for the Midwest Census Region. This region was chosen because it has a heating-dominated climate and because--in contrast to the Northeast--more of its ductwork is in crawlspaces and attics than in basements, and as noted in the introductory paragraphs, we are seeking to quantify the losses occurring in such ductwork. We recognize that the losses in basement ducts are probably less, but this is treated as a separate case for further study.

An average-size house, $1700 \mathrm{ft}^{2}$ in the Midwest (DOE 1989), will have an occupied volume of $13,600 \mathrm{ft}^{3}$ (assuming $8-\mathrm{ft}$ ceilings). The energy needed to heat $0.15 \mathrm{ACH}$ during the course of a heating system is roughly proportional to the temperature difference between the house air and the outside air. It is not strictly proportional to the temperature difference because infiltration tends to be enhanced during the coldest parts of the heating season because of nonlinearity of the driving forces (stack and wind effects). Sherman (1986) has therefore proposed the use of a special measure of temperature difference and its duration, infiltration degree days, which corresponds to the ordinary degreedays used for conduction losses but which takes these nonlinearities into account. 
A gas-industry survey (German et al. 1990) reports that over 30 years, the average number of degree (F) days in the Midwest was 6681. Sherman (1986) quotes the average ordinary degree-days for 12 Midwest cities as 6612 (65 F base), with the average infiltration degree-days under the same conditions being 7560 .

Average gas use in the region for space heating in singlefamily housing, corrected for the difference between 1989 degreedays and the 30-year average, was 104 million Btu (German et al. 1990). We estimate the average on-site efficiency of existing gas furnaces as 0.7 This is an approximate average of the 1978 salesweighted AFUE value of 0.645 (DOE 1980) and sales-weighted AFUE's for 1988-1990 ranging from 0.752 to 0.760 (GAMA News 1989-91). This implies that the average heating load in single-family housing in the Midwest is $0.7 \times 104$ million or 73 million Btu.

We compare this overall heating load with the heating load impact of fan-induced infiltration by multiplying the average incremental air-change rate by the house volume, the volume specific heat of air, the infiltration degree-days, and the factor 24 hours per day:

\section{$0.15 \mathrm{ACH} \times 13600 \mathrm{ft}^{3} \times 0.018 \mathrm{Btu} / \mathrm{F}-\mathrm{ft}^{3} \times 7560 \mathrm{~F}$-days $\times 24 \mathrm{~h} / \mathrm{day}$.}

This works out to 8.7 million Btu. Dividing this by our 73-million Btu heating load, we find that fan-induced infiltration accounts for $9 \%$ of this load.

It should be noted that this accounts only for the air-infiltration penalty of ductwork, and does not consider direct thermal losses via conduction through the duct walls, nor loss of heated air from the ducts to unconditioned spaces, which is an added penalty over and above the air-infiltration impact determined above. We now take up these other impacts.

\section{Duct Leakage}

Complementary to measurements of the impact of ducts on air infiltration is the direct measurement of duct leakage. Several experiments give information bearing on this. It is common to differentiate between leakage in the return ducts and that in the supply ducts. Often, leakage is quoted as a percentage of total flow. In particular, the return-leakage fraction (RLF) is sometimes measured without a corresponding value for the supply ducts, because it is easier to measure.

Although duct leakage contributes to the excess air infiltration discussed above, the two phenomena are not the same. To see this, imagine first a house in which the ducts do not leak at all, but in which there is only a single return register that is isolated from the rooms having supply registers. An example of this is a common layout where the return register is located in a hallway that is open to the living room but isolated from the bedrooms by closed doors. In this case, the bedrooms will be 
pressurized while the living area is depressurized. The air infiltration rate will increase when the fan is turned on, even though there is no duct leakage at all.

Now imagine a second situation in which the house is perfectly tight, but the supply and return ducts leak into unconditioned spaces. In this case, unconditioned air will be drawn into the return ducts, heated or cooled by the space-conditioning equipment, and then returned to the unconditioned space as leakage from the supply ducts. There will be no impact on air infiltration to the living space, but there will be an impact on energy use because of the waste of heating or cooling energy.

The real world is complicated by the fact that the two effects-fan-induced infiltration and leakage to unconditioned spaces--are intertwined. Typically, the returns leak more than the supply ducts, and parts of the house are pressurized while other parts are depressurized. A tracer gas measurement of air infiltration should, to a good approximation, include the infiltration into and out of the ducts, as well as that taking place in the living space, because the air in the ducts is mixed with that in the living space as it is circulated. This will be strictly true if there is no supply leakage, because then the return leaks could be treated as just an enhancement of the infiltration occurring in the depressurized zone of the house, infiltration which is measured by the reduction of tracer gas concentration due to exfiltration in the living space.

Where there are supply leaks, or where the air leaking into the returns is at a condition different srom that of the outside ambient, the energy impact of duct leaks will be different from that predicted by a straightforward prcjection based on the infiltration impact. Usually, the energy losses will be greater than the straightforward estimate.

Supply-Duct Leakage. Assume, first, that there are supply leaks. In this case, an additional impact of supply-duct leakage arises because the air that is lost from the supply ducts carries much more heat (or cooling) per cubic foot than house air. If the air in the supply ducts were no different from the house air in temperature or humidity, the energy impact of their leakage would already be included in the estimate made in the preceding section. Supply-duct leakage would look just like exfiltration losses from the living space, just as return-duct leakage looks like infiltration. However, the condition of this air is not the same as that in the living space. It is more precious than house air because it has just been warmed by the furnace or cooled by the air conditioner. In our estimate of the heating-mode energy penalty of fan-induced infiltration, the heat in the air lost by the supply ducts is underestimated to the extent of the difference between this supply-air temperature and the house-air temperature. similar considerations apply in the cooling mode.

There is a simple way to estimate this additional loss. If we make the approximation that temperature drops in the ductwork are 
small compared with the temperature rise in the furnace, then the heat lost via supply-duct leakage--unaccounted for in our fan-induced infiltration estimate--will just equal the annual heating load multiplied by the supply-duct leakage fraction.

This is perhaps not obvious, so let us focus on a parcel of air that has been lost from the supply ducts, in the heating mode. Having been warmed by the furnace, it is at some elevated temperature, say $130 \mathrm{~F}$. This air is replaced by an equal amount of ambient air that enters the system either through the house envelope or through leaks in the return ducts. The air outside is at some temperature less than the room setpoint (say, $30 \mathrm{~F}$ ). The total heat loss resulting from this leakage is therefore proportional to the temperature difference between the supply air $(130 \mathrm{~F})$ and the ambient $(30 \mathrm{~F})$.

Part of this heat loss is already accounted for in our estimate of losses based on increased air infiltration. Specifically, the energy represented by the difference between the room setpoint and the outside ambient $(70-30$ or $40 \mathrm{~F}$ in this example) is included in that es imate because it assumed that all the air lost was at room tempeisure. However, because the air in the supply ducts is much warmer, vhere is the additional penalty represented by the difference between the room setpoint and the supply-air temperature $(130$ - 70 or $60 \mathrm{~F}$ in this example). The amount of heat represented by this temperature rise is just the heat output of the furnace. Therefore, the added energy penalty of supply-duct leakage is just the entire heat output of the furnace times the supply-duct leakage fraction. The furnace output is equal to the heating load, including duct losses. Thus, the added energy penalty is, on a percentage basis, just the supply-duct leakage fraction multiplied by 100 .

It should be noted that if the supply duct leakage is into a partly conditioned space such as a basement, the effective duct losses may not be as great as the above calculation would indicate. The warm air that leaks from the ducts will raise the basement temperature, and this will in turn reduce the heat lost from the house through the floor of the first story (i.e. the basenent ceiling).

Experimental Results--Impact of Supply-Duct Leakage. Next to quantitative measures of fan-induced infiltration, perhaps the most common measure of duct leakage is the fraction of house leakage that is attributable to the ducts. It should be noted that these are two very different measurements. Fan-induced infiltration is a comparison of the normal operating characteristics of the house under two conditions--fan-on and fan-off--while the fraction of house leakage in the ducts is a special measurement made under non-normal conditions, i.e. pressurization with a blower door. Table 3 gives several reported values of the fraction of house leakage area attributable to the ductwork, together with other relevant information. The percentages shown appear quite consistent, averaging $14 \%$. From this we draw the conclusion that duct systems in various parts of the country are not hugely 
different in their leakage characteristics, although we know that there are significant local variations that may affect energy losses even if the effective leakage rea is the same. Possibly the most important variation is twe location of the return ductwork, which can reduce duct losses for basement ducts in the heating mode but enhance the losses for attic ducts in the cooling mode (see below).

Although the consistency of these percentages is encouraging, they do not yield, directly, the information we need on the amount of supply duct leakage and also the amount and characteristics of the air drawn into the return ducts. Two of the studies cited in Table 3 do provide information on the division of leakage into supply and return components. Robison and Lambert report that $33 \%$ of duct leakage occurred in the supply side, with the remainder on the return side. ThEY measured this by first isolating the supply and return ducts from each other and then obtaining plots of duct leakage vs. inside-outside pressure difference using a flow hood. When the system is restored to normal operation and the pressure difference between the inside and outside of the supply and return ducts is measured, these values can be translated into leakage volumes using the plots obtained earlier with the flow hood.

Modera 1991 gives separate information on the supply and $r$ urn leakage areas and pressure drops. Supply-duct leakage area a zraged $88 \%$ of the return-duct leakage area, while the pressure drup across the supply-duct walls averaged 51\% of the pressure drop across the return-duct walls. Assuming a modified orifice-flow model, in which leakage is proportional to an empirically determined fractional power of the pressire drop, the ratio of supply leakage to return leakage would then be equal to $0.88 \mathrm{X}$ $(0.51)^{\circ}$, where $\mathrm{n}$ is the exponent. If a value for $\mathrm{n}=0.72$ is used (Modera 1989), the supply-to-return leakage ratio becomes 0.54 , which implies that $35 \%$ of the leakage is in the supply ducts and $65 \%$ is in the returns. This is close to the split found by Robison and Lambert.

Two of the papers cited give direct information concerning duct-leakage magnitudes. Cummings et al. report an average return leakage fraction of 10.78 of total duct flow in their study of Florida houses. Proctor 1992 gives an average duct leakage (supply and return) of $20 \%$ of total flow in 61 California houses. Robison and Lambert quote an average duct leakage rate (supply and return) of $264 \mathrm{cfm}$, which would be $22 \%$ of total flow if an average $1200 \mathrm{cfm}$ total flow is assumed.

Modera 1991 gives data that, with the help of standard flow equations (Modera 1989) can be used to project duct leakage in his experiment. Using an exponent of 0.65 , supply leakage was estimated to be $135 \mathrm{cfm}$ while return leakage was $285 \mathrm{cfm}$. This implies a total leakage of $-30 \%$ of total flow if the total flow is near the $1200 \mathrm{cfm}$ commonly specified.

It should be noted that the location of the filter can greatly affect the return leakage fraction. If the filter is near the 
register, it will contribute to the depressurization of the entire return duct, whereas if it is in the furnace, it will not. Therefore, return leakage is expected to be greater in the former case.

Although there is some variation from one duct system to the next and from one study to the next, we use the above information to define a "typical" duct system with two-to-one split between supply leakage and return leakage, and estimate an average overall

Table 3. Duct Leakage Information from Several studies

\begin{tabular}{|c|c|c|c|}
\hline Reference & $\begin{array}{l}\text { Sample Size* } \\
\text { and Location }\end{array}$ & $\begin{array}{l}\text { Percent of } \\
\text { House Leak- } \\
\text { age in Ducts }\end{array}$ & $\begin{array}{l}\text { Other Infor- } \\
\text { mation on } \\
\text { Leakage }\end{array}$ \\
\hline Caffey 1979 & $\begin{array}{l}40 \text { Houses } \\
\text { Texas }\end{array}$ & 14 & \\
\hline Cummings et al. 1991 & $\begin{array}{l}99 \text { Houses } \\
\text { Florida }\end{array}$ & 13 & $\begin{array}{l}\text { Avg. return } \\
\text { leakage frac- } \\
\text { tion }=0.107\end{array}$ \\
\hline Gammage et al. 1984 & $\begin{array}{l}7 \text { Houses } \\
\text { Tennessee }\end{array}$ & 15 & \\
\hline Modera 1991 & $\begin{array}{l}31 \text { Houses } \\
\text { California }\end{array}$ & $s$ & $\begin{array}{l}\text { Fan-driven } \\
\text { duct leakage } \\
\text { was } 35 \% \text { from } \\
\text { supply and } 65 \% \\
\text { from return } \\
\text { ducts** }\end{array}$ \\
\hline Proctor 1992 & $\begin{array}{l}61 \text { Houses } \\
\text { California }\end{array}$ & & $\begin{array}{l}\text { Duct leakage } \\
\text { averaged } 20 \% \\
\text { of flow }\end{array}$ \\
\hline $\begin{array}{l}\text { Reinhold and } \\
\text { Sonderegger } 1983\end{array}$ & 30 Houses & 14 & \\
\hline $\begin{array}{l}\text { Robison and } \\
\text { Lambert } 1989\end{array}$ & $\begin{array}{l}20 \text { Houses } \\
\text { Pacific } \\
\text { Northwest }\end{array}$ & 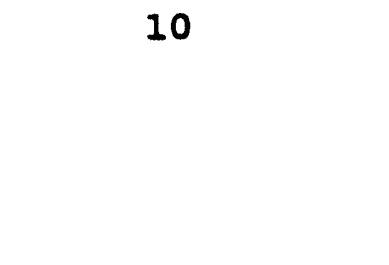 & $\begin{array}{l}\text { Fan-driven } \\
\text { duct leak- } \\
\text { age was } 33 \% \\
\text { from supply } \\
\text { and } 67 \% \text { from } \\
\text { returnducts. }\end{array}$ \\
\hline $\begin{array}{l}\text { * Sample size given } \\
\text { fraction of house leak } \\
\text { This is sometimes sma } \\
\text { report. }\end{array}$ & $\begin{array}{l}\text { refers to num } \\
\text { age area that } \\
\text { liler than the }\end{array}$ & $\begin{array}{l}\text { ber of houses } f \\
\text { ras in the ducts } \\
\text { overall sample }\end{array}$ & $\begin{array}{l}\text { for which the } \\
\text { was measured. } \\
\text { size for the }\end{array}$ \\
\hline
\end{tabular}


duct leakage of 20-25\% of total flow--7.5\% in the supply ducts and $15 \%$ in the returns. In this case, the discussion in the preceding section leads to the conclusion that supply-side leakage contributes an additional $7.5 \%$ to the duct losses, beyond the $9 \%$ already accounted for in fan-induced infiltration.

There is one additional, relatively minor effect, caused by the small amount of air that leaks into the return duct and out the supply duct on the first pass, without ever reaching the house. This adds about $1 \%$ to the estimates made above.

The estimates for all these leakage and infiltration effects total 17.5\%. Perhaps a "typical range" of 15-20\% might be accepted as reasonable. It should be noted that we have yet to consider the impact of return-duct leakage at a temperature different from the ambient. This is now discussed.

Return Leakage at Temperatures other Than Ambient. Everything that has been said so far assumes that the air leaking into the return ducts is at or near ambient conditions. To the extent that this is not so, the impact of duct leakage on overall efficiency can be significantly altered. The impact can go in either direction, increasing or decreasing the losses that would otherwise occur.

If the returns are in a partly conditioned space such as a basement, the temperature of the air leaking into the returns is likely to be significantly higher than ambient (heating mode). As a result, the losses due to duct leakage will be less than what was calculated, since the calculations assumed that the air leaking into the return ducts had to be heated from the ambient condition.

If the returns are in a space that is farther removed from the desired condition than even the ambient is, return leaks can greatly increase the overall impact of duct losses. This typically occurs in the cooling mode, in installations where returns are located in the attic.

Energy-Use Impact of Return Leakage. As discussed above, leakage into return ducts can have a significant impact on the overall energy efficiency of the duct system. This effect can be decidedly negative in the cooling mode in systems with attic returns. Cummings and Tooley (1989) state that if the return leak is from the attic, a $20 \%$ return leak may cut the net efficiency of the air conditioner by about 50\% and nearly double the cooling energy consumption. Such dramatic effects are expected to have the greatest societal impacts where latent cooling loads are high and where attic returns are common. Such conditions hold throughout the hot-humid area of the south from Florida to Texas, where single-story slab-on-grade housing is the norm and the attic is the usual location in which builders install ductwork.

Placement of heating ducts in a basement will have the opposite effect of reducing duct energy losses below the value that would otherwise be predicted on the basis of fan-induced infiltration and supply-duct leakage. We have no experimental 
measurements, but simulations done with an experimentally validated computer program (Jakob et al. 1986) are illustrative. In these simulations of a Columbus, OH house with basement ductwork, supplyand return-duct leakage values were assumed to equal each other, with no variation in fan-induced infiltration from one run to the next. Under these conditions, the following results were obtained:

- In an uninsulated basement, reducing total leakage from 20\% to $10 \%$ reduced energy consumption by $3.7 \%$.

- In a basement with R-8 walls, reducing total leakage from $20 \%$ to $10 \%$ recuced energy consumption by $3.0 \%$.

Since fan-induced infiltration did not vary over these runs, a calculation of expected savings based on supply losses alone would predict a $5 \%$ savings in either case, since half the total leakage was from the supply ducts. The reduced savings in the basement situation can be viewed as equivalent to the statement that not all of the losses at the higher leakage rate were really lost; hence reducing the leakage will not save as much energy as would otherwise be the case. The implication is that in the uninsulated basement, only $3.7 / 5.0 \times 100$ or 748 of the "losses" were really lost, while in the insulated basement, only $3.0 / 5.0 \times 100$ or $60 \%$ of the "losses" were really lost. It is to be expected that the real losses will be less in the insulated basement than in an uninsulated basement, since the insulated basement retains more effectively heat that escapes from the ductwork.

Which of the two effects discussed immediately above is more important on a national basis? A precise determination of this is beyond the scope of this report. A previous study (Andrews and Modera, in press) estimated an energy savings potential for the year 2020 of 0.38 quads ( 1 quad $=10^{\text {ts }}$ Btu) for existing and new houses with ducts in unconditioned spaces in the South and West, and 0.23 quads for existing and new houses with basement ducts in the Midwest and Northeast. A portion, perhaps 50\%, of the former group falls in the category of hot-humid location and attic ductwork. Thus, it is believed that the two effects, one increasing duct losses beyond the basic calculation, the other reducing them, are of the same order of magnitude nationally. Hence, neither will be included in our benchmark evaluation of the losses associated with the "typical" duct system, although it is recognized that they will contribute to a broad "spread" of loss percentages around this mean value.

Duct Losses Via Conduction

We now turn our attention away from the convective duct-loss mechanisms discussed in the preceding sections to conductive transfer of heat through the walls of ducts located in or adjacent to unconditioned spaces.

For all of the effort that has been directed toward leakage losses, relatively little has been reported on conductive losses. However, two studies that do report conductive losses are both large efforts that include both experimentation and simulation. 
One of these is the SP-43 project supported over a six-year period by the American Society of Heating, Refrigerating, and Air-Conditioning Engineers (ASHRAE), the Gas Research Institute (CRI), and the U.S. Department of Energy (DOE). The study was carried out at Battelle-Columbus Laboratories in Ohio. The second study is a product of ongoing research at Lawrence Berkeley Laboratory (LBL). A third report that provides data from one research house is consistent with the above two more extensive studies.

Results of the SP-43 work were generally obtained by analyzing results obtained from a computer model that was validated using experimental data taken from two houses with basement ductwork in Columbus, Ohio. Most of these papers compare one type of forced-air system with another. The first paper to compare forced-air systems with electric baseboard is Crisafulli et al. 1989. The terminology used by SP-43 to characterize efficiencies is complex; it is sufficient here to note that they define a system Index (SI) as a bottom-line figure of merit inversely proportional to seasonal energy consumption. A Furnace Efficiency (FE) is equal to the ratio of seasonal heat output to fuel input. We can therefore obtain a figure of merit relating to duct performance only by taking the ratio SI/FE, if we are willing to ignore any impact that the duct system may have on the furnace. (For the baseboard system, the ratio SI/FE equals unity, since there are no ducts.)

In Crisafulli et al. (1989), simulation runs on a two-story house over a crawlspace in Portland, $O R$ and in Seattle, WA were done for several configurations, including an electric baseboard system and a gas-furnace system with ducts. Duct leakage was set equal to zero. There is no fan-induced infiltration in the model. Thus, the only duct losses are conductive.

One difficulty in interpreting this paper is that they used different house characteristics for different runs of the model. However, for four runs, two in Portland and two in seattle, the same house was used for electric baseboard and for the gas furnace. The only difference between the seattle and Portland cases was that in seattle the ducts were insulated to $R-6$ while the crawlspace perimeter was uninsulated, while in portland the ducts were uninsulated but the crawlspace perimeter had R-11 insulation.

The results were that in seattle the value of SI/FE for the gas furnace and ductwork was 0.793 (compared with 1.0 for the baseboard), while in Portland, SI/FE equaled 0.812 (compared with 1.0 for baseboard). The average living-space temperatures were within $0.3 \mathrm{~F}$ of each other in Seatele and within $0.2 \mathrm{~F}$ in Portland.

The interpretation we give to these results is that the net conduction losses for insulated ducts in an uninsulated crawlspace or for uninsulated ducts in an insulated crawlspace were about $20 \%$ of the heat input from the furnace.

The other major research project to provide data on conductive losses is the Lawrence Berkeley Laboratory effort (Modera 1991). 
Extensive simulations were performed on a single-story California house with supply ducts located in the attic and returns located in a crawlspace. The ducts were assumed to have $R-4$ insulation.

In parallel with this simulation effort, field measurements of conductive losses were obtained by measuring the air temperature at the furnace plenum and at various points in the ductwork. The fractional energy loss by conduction was calculated by dividing the average temperature drop through the longest and shortest supply ducts by the temperature rise in the furnace. Because the temperature at the end of a supply duct is not affected by leakage from that duct (except for the impact of reduced flow rates on convective heat transfer coefficients), this approach isolates the conductive component of the duct losses.

In the simulations, conductive losses amounted to $13 \%$ of delivered heat from the furnace, whereas in the field these losses amounted to $23 \%$ of delivered heat. The paper's author favors the field results for the following reasons, besides the obvious one of favoring data over theory:

- Ductwork in the field was insulated to less than R-4, on average.

- Ducts in the field were longer than those simulated.

- The temperature differences driving conduction were higher in the field.

- The residence time of the air in the ducts was longer in the field.

In an experiment dovoted primarily to the effects of zoning, Leslie et al. (1988) shows temperature drops in the ductwork that average $26 \%$ of the temperature rise in the furnace. These results, obtained under continuous operation of the furnace during recovery from setback, are viewed as consistent with the results of Crisafulli and Modera.

The data on the subject of conductive losses is not as voluminous as that on leakage and infiltration losses. Nevertheless, they do support the tentative conclusion that these losses are typically in the 20-25\% range. since we estimated the leakage and infiltration losses at 15-20\%, the two effects are of comparable importance. We note that the results for conductive losses were obtained for ductwork that is insulated to levels common in current construction practice.

\section{Overal1 Duct-Loss Measurements}

Some experiments attempted to quantify the overall magnitude of the duct losses without attempting to compartmentalize them with respect to specific mechanism. Some of these experiments reported a difference in energy use between a sample of houses with ducted systems and an approximately equivalent sample with baseboard heating systems. Others report a direct comparison of heat delivered to the conditioned space with heat delivered by the furnace. One large study reported the difference between ducted and baseboard systems in terms of specific k-factors. 
The $\mathrm{k}$-factor is defined as the slope of a regression line through a scatterplot consisting of one point for each day of operation. The vertical axis is the amount of heating energy used for that day, while the horizontal axis is the difference between the average outdoor temperature for the day and some base temperature, usually taken as $65 \mathrm{~F}$ (though varying this choice will not affect the slope of the regression line, merely offsetting it to left or to right). A specific $k$-factor is a $k$-factor divided by the area of the conditioned space. The specific k-factor should divide out most of the variation caused by differences in the average floor area between the two groups of houses being compared.

A strong argument can be made for the use of specific $\mathrm{k}$-factors rather than overall seasonal energy-use values as measures of the impact of ductwork on energy consumption. This is because the ducted system has only a single setpoint, whereas the baseboard system has many. Thus, the average level of thermal comfort may be different in the two systems. This will affect the position of a regression line to the left or to the right on the horizontal axis, but it should not affect the slope. Thus, if occupants with baseboard systems routinely use continuous setback of lesser-used spaces as an energy conservation strategy, the energy penalty of ductwork will be exaggerated, while if they use the added control freedom of individual room thermostats to "take back" thermal comfort, the energy penalty of ductwork will be underreported. Within limits, the specific k-factors will not be affected by these strategies.

Lambert and Robison (1989) studied a sample of 256 conventionally built houses in the Pacific Northwest, $40 \%$ of which had ducted forced-air heating systems with electric-resistance furnaces while the remainder had electric baseboard heat. The two groups of houses were judged to be similar in all respects except size. Average values of the specific k-factor were calculated for the ducted group and the baseboard group. For the ducted group, the average rpecific $\mathrm{k}$-factor was $0.2805 \mathrm{Btu} / \mathrm{h}-\mathrm{F}-\mathrm{ft}^{2}$, while for the baseboard gre $\mathrm{p}$ it was $0.2005 \mathrm{Btu} / \mathrm{h}-\mathrm{F}-\mathrm{ft}^{2}$. The ducted value was $40 \%$ greater than the unducted value. Everything else being equal, this would indicate that the energy losses attributable to the ductwork are $(1-0.2005 / 0.2805) \times 100=29 \%$ of furnace output.

For a group of energy-efficient houses constructed under a utility incentive program, the average specific $k$-factor was 0.1484 for the ducted homes and 0.1315 for the homes without ducts, Here the calculated duct losses were only $11 \%$ of furnace output; moreover, this percentage is taken on a smaller base energy use because of the better construction of these houses. The energy losses due to ductwork in the control group, as measured by specific $k$-factors, are equal to $0.2805-0.2005=0.0800$ Btu/h-F-ft ${ }^{2}$, while the duct losses for the energy-efficient group are given by the difference $0.1484-0.1315=0.0169 \mathrm{Btu} / \mathrm{h}-\mathrm{F}-\mathrm{ft}^{2}$. Thus, the latter group's duct losses were only $21 \%$ as great as in the control group. (Another way to arrive at this figure is to note that the heating load is reduced by $47 \%$ in the energyefficient group while the duct losses, as a percentage of heating load, are reduced by $62 \%$. The combined impact is to reduce energy 
losses in the ductwork by 79\%.) The lesson here is that with careful construction, duct losses can be decisively dealt with.

Another study based on a slightly different subset of the same sample of houses (Parker 1989) found that the conventionally built homes with baseboard heat used $21 \%$ less energy than the conventionally built ones with ducts, when the energy use was normalized to house floor area. The discrepancy between this result and the $29 \%$ found using the specific k-factors may be due to a thermal comfort takeback effect in the baseboard homes, but since no data on average space temperatures are given, it is not possible to be sure. The judgement of this reviewer is that the $29 \%$ figure is the best representation available of the difference between the performance of the ducted systems as found and a hypothetical "loss-free" ducted system that would provide the same level of thermal comfort.

other studies provide additional information, although not so systematically as the above. Leslie et al. 1988, in a study mainly aimed at zoning, reported that "duct losses were $60 \mathrm{cfm}$ and $29 \%$ of furnace output." The $60 \mathrm{cfm}$ is an unusually low value for duct leakage.

Modera (1992), in a presentation to the American Society of Heating, Refrigerating, and Air-Conditioning Engineers, stated a general conclusion from years of research that "duct efficiencies range fism $60 \%$ to $70 \%$, "that is, net duct losses can be expected to fall in the range $30 \%$ to $40 \%$.

In a weatherization study, Hagood and Cooper (1984) stated that energy savings in homes with electric central furnaces and ducts averaged $4866 \mathrm{kWh}$, while savings in homes with electric room heaters averaged $3552 \mathrm{kWh}$. If one assumes that the savings are proportional to the energy use before weatherization, then the ducted systems used $37 \%$ more energy than the unducted systems, or equivalently (assuming no between-group variations in house size or thermal comfort level), $27 \%$ of the energy used by the ducted systems was duct losses.

On the low side of the duct-efficiency spectrum, Goldschmidt and Hart (1982) reported on a mobile home with a heat pump, for which the season-total heat delivered by the heat pump was 1.61 times the electric energy used, but the heat delivered to the space was only $89 \%$ of the electric input. That is, the heat pump with ducts was less efficient overall than electric-resistance baseboard! Duct losses in this case were a horrendous $45 \%$.

The results of these studies are summarized in Table 4 . 


\begin{tabular}{lc}
\hline Table 4. Reported Values of Overall Net Duct Losses \\
\hline \multicolumn{1}{c|}{ Study } & $\begin{array}{l}\text { Net Duct Loss as } \\
\text { Percentage of } \\
\text { Furnace output }\end{array}$ \\
Parker 1989 & 21 \\
Lambert and Robison 1989 & 27 \\
Hagood and Cooper 1984 & 27 \\
Leslie et al. 1988 [see Note] & 29 \\
Modera 1992 & $30-40$ \\
Goldschmidt 1982 & 45 \\
Note: Gross duct loss in house with basement ductwork
\end{tabular}

The Bottom Line

Considering loss factors independently, we arrived at ranges of 15-20\% for infiltration and leakage losses and 20-25\% for conductive losses. Adding the midpoints of these ranges yields an overall estimate of $40 \%$, while treating them as cumulative effects results in a somewhat lower estimate of $34 \%$. A strictly correct treatment is probably somewhere in between. The overall loss estimates shown in Table 4 are generally somewhat lower, although the Florida researchers have suggested much larger losses in their locale. As a final "bottom line" estimate, we believe that 30-40\% is a reasonable range for duct losses in houses where the ducts are located in an unconditioned space, with "problem" ducts such as those found in some of our manufactured housing and attic ductwork in hot-humid climates having losses above the range.

Basement ductwork is generally believed to be less lossy than ductwork placed in attics or vented crawlspaces. If we use the work of Jakob et al. (1986) to quantify this effect as described above, we may characterize the basement as saving from 25\% to $40 \%$ of the heating energy that would otherwise be lost from the ducts to the outside. This would raise our benchmark $65 \%$ efficiency to the $75 \%$ - $80 \%$ range.

Thus, overall, we believe that the net efficiency of the vast majority of ducted space conditioning systems today can be characterized by a broad band running from $50 \%$ to $80 \%$, with the majority falling in the $60 \%$ - $70 \%$ range. 


\section{References}

Andrews, J.W. and Modera, M.P. Energy Savings Potential for Advanced Thermal Distribution Technology in Residential and Small Commercial Buildings. Brookhaven National Laboratory and Lawrence Berkeley Laboratory joint report, in press.

Caffey, G. Residential Air Infiltration. ASHRAE Trans., Vol. 85, pt. 1, 1979 .

Crisafulli, J.J.; Cudnik, R.A.; and Brand, L.R. Investigation of Regional Differences in Residential HVAC System Performance Using the SP-43 Simulation Model. ASHRAE Trans,, V. 95, Pt. 1, pp. 915-29, 1989 .

Cummings, J.B. and Tooley, J.J., Jr. Infiltration and Pressure Differences Induced by Forced Air systems in Florida Residences. ASHRAE Trans., Vol. 95, Pt. 2, 1989.

Cummings, J.B.; Tooley, J.J., Jr.; and Moyer, N. Investigation of Air Distribution System Leakage and Its Impacts in Central Florida Homes. Florida Solar Energy Center Report FSEC-CR-387-91, January 1991.

DOE 1980. Energy Efficiency Standards for Consumer Products. DOE/CS-0166, June 1980, p. D4-5.

DOE 1989. Housing Characteristics 1987. DOE/EIA-0314(87), MaY, 1989 .

GAMA News. Gas Appliance Manufacturers Association, Arlington, VA. Issues of March 4, 1991; March 9, 1990; and March 2, 1989.

Gammage, R.B.; Hawthorne, A.R.; and White, D.A. Parameters Affecting Air Infiltration and Air Tightness in Thirty-one East Tennessee Homes. Proc. ASTM Symp. on Measured Air Leakage Performance of Buildings, Philadelphia, PA, 1984.

German, M.I.; Ittelag, R.L.; Pavle, J.; and Curtis, A. Residential Gas Market Survey: 1989. American Gas Association, Arlington, VA, July 1990.

Goldschmidt, V.W. and Hart, G.H. Heat Pump System Performance: Experimental and Theoretical Results. ASHRAE Trans., V. 88, pp. $479-90,1982$.

Hagood, A.T. and Cooper, P.G. TVA Home Insulation Program Energy Saving. Tennessee Valley Authority Report No. TVA/OP/ECR-84/24, 1984

Jakob, F.E.; Locklin, D.W.; Fischer, R.D.; Flanigan, L.J.; and Cudnik, R.A. SP43 Evaluation of System Options for Residential Forced-Air Heating. ASHRAE Trans., V. 92, Pt. 2, 1986. 
Lambert, L.A. and Robison, D.H. Effects of Ducted Forced-Air Heating systems on Residential Air Leakage and Heating Energy Use. ASHRAE Trans. Vol. 95, Pt. 2, 1989.

Leslie, N.P.; Carrington, J.S.; Ghassen, P.G.; and Hedrick, R.I. Conventional Research House Zoned Heating--Test Results. Topical Report, January 1987- March 1988. GRI-5086-245-1360, September 1988.

Matthews, T.G.; Thompson, C.V.; Monar, K.P.; Dudney, C.S. Impact of Heating and Air Conditioning system operation and Leakage on Ventilation and Intercompartment Transport: Studies in Unoccupied and occupied Tennessee Valley Homes. J. Air Waste Manage. Assoc. 40: 194-198 (1990).

Modera, M.P.; Dickerhoff, D.; Jansky, R.; and Smith, B. Improving the Energy Efficiency of Residential Air Distribution Systems in California. LBL-30886, May 1991.

Modera, M.P. Residential Air-Distribution System Performance: Field Examination and Simulation Results for California. Presented at the ASHRAE Winter Meeting, Anaheim, CA, January 28, 1992.

Palmiter, L.S.; Brown, I.A.; and Bond, T.C. Measured Infiltration and Ventilation in 472 All-Electric Homes. ASHRAE Trans. V. 97, Pt. 2, 1991.

Parker, D.S. Evidence of Increased Levels of Space Heat Consumption and Air Leakage Associated with Forced Air Heating Systems in Houses in the Pacific Northwest. ASHRAE Trans. V. 95, Pt. 2, 1989.

Proctor, J. A Field Study of Duct Leakage in Residential Heating and Cooling systems. Presented at the ASHRAE Winter Meeting, Anaheim, CA, January 28, 1992.

Reinhold, C. and Sonderegger, R.C. Component Leakage Areas in Residential Buildings. Proc. Fourth Air Infiltration Centre Conf., Elm, Switzerland, set 26-28, LBL-16221, 1983.

Riley, M.; Piersol, P.; and Lubun, M. Formaldehyde and Radon: Results Under the R-2000 Program. Proc. IAQ '88: Managing Indoor Air for Health and Energy Conservation, Atlanta GA, CONF-860446-, April 1986, pp. 309-317.

Sherman, M.H. Infiltration Degree-Days: A Statistic for Quantifying Infiltration-Related Climate. ASHRAE Trans., Vol. 92, Pt. 2, 1986 .

Sherman, M.H. Analysis of Errors Associated with Passive Ventilation Measurement Techniques. Building and Environment, Vol. 24 , No. 2, pp. 131-139, 1989. 
zoning is defined as the ability to heat and cool different portions of a building to different setpoint temperatures for part or all of the diurnal cycle. The conventional aiternative to zoning is a system that heats or cools in response to a single control point. Such systems will be referred to hereafter as single-zone systems. Systems that employ zoning will be calleci multizone systems or, simply, zoned systems. It should be noted that single- zone systems can employ time-based control strategies such as night setback; this is not considered zoning in this review, since it can be done using a single control point.

zoning generally has one or both of the following oijectives: (1) improved thermal comfort, and (2) energy conservation. Although improved thermal comfort is an important value, the main objective of this review is to assess the current state of knowledge concerning the energy-savings potential of zoning.

zoning can achieve improved thermal comfort if the single-zone system does not condition the entire space to the temperature profile desired by the occupants. This can arise either because the occupants desire uniform heating or cooling, which the system does not provide (e.g. because of poor design or uneven solar gains), or because the occupants prefer nonusiform space conditioning. Zoning provides added control freedoin to the occupants, who can thereby bring the condition of the space to a closer approximation to their desires.

zoning can save energy if the occupants are willing to accept reduced levels of thermal comfort in at least part of the structure for at least part of the tine. In some cases it may be possible to save energy and improve comfort at the same time, e.g. if the single-zone system for some reason overconditioned parts of the space beyond the wishes of the occupants. The more usual condition, however, is a tradeoff between comfort and energy savings.

This discussion of the literature on zoning begins with predictions of energy savings, followed by discussion of zoning strategies and issues that can influence the potential of zoning to save energy. We then discuss two major field studies that bear on this potential. Finally, we assess the significance of these results.

\section{Predicted Energy Savings}

During the mid-1980's there was a burst of interest in zoning as an energy conservation strategy in residential housing. Bin-type analyses carried out at that time indicated that zoning did have considerable energy savings potential. Two such studies are representative of work done at that time.

In the first of these studies, based on Knoxville, TN weather, Nephew et al. (1985) predicted significant energy savings for a 
two-zone strategy for the heating season, in which the bedrooms are maintained at a constant $60 \mathrm{~F}$ temperature night and day, while the areas occupied during the waking hours are cycled between $60 \mathrm{~F}$ and $70 \mathrm{~F}$, with the setback occurring over 8 nighttime hours. This was predicted to save $27 \%$ on heating energy relative to a strategy that held the entire living space at $70 \mathrm{~F}$ all the time.

A second study (Andrews and Murray 1987a) advocated downsizing the furnace as a technical key to zoning a forced-air system. Simulations using a lumped-parameter model were performed for Pittsburgh and Albany. For a zoning strategy similar to the above (with the difference that the bedrooms are allowed to float below $60 \mathrm{~F}$ during the day), the predicted savings were $30 \%$ to $32 \%$, relative to a constant $70 \mathrm{~F}$ setpoint. This study assumed a house with a 12-hr thermal relaxation time (see below for further discussion of this factor).

one factor that was addressed in both reports was that zoning energy savings ought to be measured against the best strategy that a single-zone system can utilize, with levels of thermal comfort that are no worse at any time than those found in the zoned system. That is, the zoned strategies discussed above should be compared, not with a constant $70 \mathrm{~F}$ at all times, but with a night-setback strategy that sets the whole house back to 60 F for 8 nighttime hours.

Such a night-setback strategy was predicted by Andrews and Murray to save $13 \%$ to $15 \%$ relative to the baseline, with the result that zoning would save $20 \%$ if the setback strategy is used as the base. Nephew and Moyer predicted savings of $9 \%$ to $15 \%$ for night setback, so that their zoning strategy was predicted to save between $14 \%$ and $20 \%$ relative to the single-zone night setback.

Savings in the vicinity of $20 \%$ were judged to be worth going after. A program plan developed for the DOE (BNL 1986) therefore recommended that zoning play a strong role in any research program in thermal distribution. Although the DOE program did not proceed at that time, other research on zoning has since been performed, including field evaluations in two test houses. Although all the questions are far from answered, we are in a better position now than we were then to evaluate the energy-saving potential and thermal comfort tradeoffs involved with zoning.

\section{Zoning strategies}

In the mid-1980's, a study was conducted at a national laboratory (Andrews and Murray 1987b) to define a set of plausible strategies for zoning in small buildings. These strategies were divided into categories as follows:

I. Separate space conditioning systems for each of two (or more) zones.

II. Modifications to a single duct system to facilitate varying the fraction of the heat or cooling output delivered to each $z$ one. 
III. A conventional duct system that delivers a constant fraction of the heat or cooling output to each zone, with variability achieved by means of supplemental sources.

The first category is straightforward, requiring no new technology. More appropriate for larger houses, it was the strategy chosen for $75 \%$ of the zoned systems reported in a recent survey of California builders (Modera 1990, p.22).

Modifications suggested to facilitate energy conservation with the second strategy included use of a variable-output furnace; use of a downsized, fixed-output furnace; and routing of warm air through wall cavities to capture benefits of radiant heating in a forced-air system. Control of air flows would be by means of dampers and/or by distributed blowers. Several manufacturers are now marketing such systems.

The third category included such things as use of radiant panels to supplement a basic level of heating via the forced-air system; taking advantage of variable internal and solar gains to capture some of the benefits of zoning; passive cooling of the sleeping zone in hot climates; and use of distributed electric-resistance backup heaters (as opposed to a central resistance coil) with heat pumps in cold climates. This last option was predicted, in a scoping study for Albany, NY (Andrews 1986), to save $14 \%$ on total purchased power for space heating and $32 \%$ on peak demand.

The Warm-Room concept. Perhaps the lost extreme type of zoning strategy is one suggested by Kensill (1983). This strategy, called the warm room, is a radical attempt to reduce the heating bills of economically distressed people by effectively heating only a small part of the house, while keeping the rest of the house just warm enough to prevent damage to the building system or its contents. The strategy was said to produce savings of about half the energy that would otherwise be required. Although no data were given by Kensill, the estimate seemed plausible in view of the drastic reduction in thermal comfort involved. Wagner and Diamond (1986) reported an average $26 \%$ savings on gas in five warm-room retrofit houses. The percentage savings for heating alone were greater than thij, since gas used for purposes other than heating was included in the total consumption, diluting the percentage heating savings.

In forced-air systems, however, one would have to be concerned with unintended effects that might develop in such a strategy if, for example, most of the registers in the house were closed off. This would result in significantly higher pressures in the entire duct system, with consequent increases in duct leakage. This could be eliminated in many cases by reducing the fan speed and by sealing off unused sections of the duct system; such modifications would usually be beyond the capability of the homeowner. Even if this were done, the reduced air flow across the furnace heat exchanger would impair furnace efficiency to some extent. 
In hydronic systems, the homeowner could stuff baseboard heat exchangers in semi-heated rocis with insulation, adjusting the amount of stuffing until the desired temperature reduction is achieved. In general, measures such as these, while usable in some areas, probably involve too great a luss in thermal comfret to achieve a very wide tilization rate.

\section{Issues Related to Zoning}

Several papers dealt with issues related to zoning. These issues concern technical reasons why zoning may have difficulty achieving the degree of energy savings envisioned in straightforward analyses of the type discussed above. These issues include the impact of the building's thermal time constant, the possibility that an oversized furnace may be needed for recovery from setback, the effect that occupancy schedule can have on achievable savings, the need for return-duct dampers, and additional losses in zoned systems that impose higher nressures on ducts during part-ioad cperation.

Griffith (1985) used a test house in New Jersey to study the effect of thermal relaxation times in reducing the energy savings achievable in a night-setback strategy. This is also an issue when considering zoning strategies that involve diurnal changes in setpoint temperature in one or more zones of the house. The house had a 23.4-hour thermal relaxation time (the time for the indoor-outdoor temperature difference to drop to $37 \%$ of its original value in the absence of heat input). Under these conditions, the energy savings predicted with an $8-\mathrm{hr} 10.8 \mathrm{~F}$ night setback were determined to be $7.6 \%$. This was $50 \%$ of what would have been the case assuming no time lag due to thermal mass.

Hedrick et al. (1992) review the literature on furnace oversizing and find current recommendations to be on the low side. That is, in contrast with the prevailing opinion that furnaces are oversized too much, they advocate oversizing furnaces by more than $100 \%$ to insure a recovery period of less than two hours from $10 \mathrm{~F}$ night setback. The relevance of this to zoning is that zoning, like night setback, requires recovery from a lower temperature (heating mode). One factor to keep in mind, however, is that with zoning it may not be necessary to bring the whole house up from setback all at once. Some strategies require bringing the whole house up from setback. to nominal temperature in the morning, after which unused areas (e.g. the bedrooms) are allowed to float back down during the day. Other strategies leave the bedruom area set back all the time, relying on localized radiant spot heaters (e.g. in the bathroom) to provide thermal comfort for dressing. The latter type of strategy could use a much smaller furnace than the former, which has advantages if a fixed output furnace is to be used (Andrews and Murray 1987a). If the control strategy selected does require an oversized furnace, it will probably have to be the modulating type to avoid excessive pressures in the active portion of the duct system (Modera 1990). 
Modera (1990) performed a survey of builders and some detailed simulations of zoned residential forced-air systems. This work identified two major issues: (1) the impact of occupancy schedule on the energy savings achievable with zoning, and (2) the need for return-duct dampers in a zoned system. The energy savings from zoning are greatly reduced if the house is not occupied in the daytime, because then the whole house could be set up (cooling) or set back (heating) during the day, even without zoning. Thus, any energy savings accruing to zoning during the daytime are illusory relative to what one could do even without zoning. A simple calculation based on the California Energy Commission's zone-temperature profile predicted that for $a$ house that is unoccupied during the daytime, actual energy savings from zoning would be only $-60 \%$ of the predicted value in the cooling mode, and would be zero in the heating mode. Again, the reduced savings estimate is derived from the assumption that the house which is unoccupied during the day would be set up or back during the unoccupied hours, even without zoning.

The report also stresses that if a zoned system is implemented with dampers only on the supply side, this will result at least one of the following two effects. Taking a two-zone system as an example, if the zones are not well isolated from each other, then the lack of a return damper in the zone that is not calling for heat will result in air being drawn into that zone from the zone that is calling for heat. This will inhibit the desired effect of a temperature difference between the zones. On the other hand, if the zones are isolated from each other, then the lack of a damper on the return ducts will result in depressurization of the zone that is not calling for heat. This will produce an increase in the air infiltration rate from the outside.

\section{Experimental Results--Setback}

Experimental results on night setback are germane to zoning for at least two reasons. One is that night-setback experiments can shed light on the impact of the thermal relaxation time on energy savings expected from diurnal setback or setup of individual zones. The $r$ ther is that single-zone night setback provides the appropriate baseline against which true zoning should be evaluated. The time-constant issue was already discussed above, in connection with Griffith (1985). Other measurements of energy savings from this strategy are discussed here.

Although it is a prediction based on model runs, we include the value given by Jakob et al. (1986) here because the model is based on experimental validations. Using the ASHRAE SP-43 model, based on two single-family houses in Columbus, Ohio, they derive energy savings of $14 \%$ to $15 \%$ in Pittsburgh for a whole-house setback of $10 \mathrm{~F}$ for 8 nighttime hours.

Leslie and Kazmer (1989) measured (in Chicago) an energy savings of $15 \%$ for a single-zone strategy in which the whole house was set back $12 \mathrm{~F}$ for 8 nighttime hours. The heated area of the 
house included an uninsulated basement whose temperature floated $\sim F$ below that of the living area.

In a brief study that complements the information obtained on night setback, Flanigan (1986) showed that maintaining the temperature of the upper story of a two-story home at a level $12 \mathrm{~F}$ below that of the lower story saved $19 \%$ on heating energy, under conditions where the outdoor temperature fluctuated between $15 F$ and $35 \mathrm{~F}$. Here, part of the house is set back all the time, in contrast to night-setback studies that set back all of the house part of the time.

Another experiment (Levins 1989) measured the effect of closing off a portion of a test house in Tennessee that was equipped with both a heat pump and an electric furnace. In the heating mode, closing off $20.7 \%$ of the house volume resulted in $16.8 \%$ energy savings when the electric-resistance furnace was on, in contrast to only a $9.7 \%$ savings when the heat pump was operating. A possible explanation offered was that the duct losses were a larger fraction of the heating output when the heat pump was operating, because the system had to operate a longer period of time to deliver a given amount of heat. This would increase the infiltration impact of operating the forced-air system, relative to the amount of delivered energy. To put this another way, if closing off a certain portion of the house increases the duct losses by a certain fraction, this effect will be more significant for the heat pump than for the electric furnace because the heat pump incurs greater duct losses to begin with. Hence, the savings from zoning will be less for the heat pump because of this added penalty. It should be noted that the argument given was qualitative; simulations would be useful in exploring its validity.

In the cooling mode, the energy savings that accrued from zoning off the same $20.7 \%$ of the house were negligible--ranging from $0.8 \%$ to $2.4 \%$. Temperature measurements showed that the rooms were effectively zoned off, and that the heat pump's operating conditions were not significantly affected by the zoning change. No explanation for the lack of energy savings in the cooling mode was found.

\section{Summary of Predicted and Experimental Results--Night Setback}

The following table summarizes the results for night setback discussed above. As a basis for comparison, a figure of effectiveness $E$ is defined as $E=S /(X * T)$, where $S$ equals the predicted or measured energy savings in percent, $x$ is the fraction of the day that the living space is set back, on a whole-house equivalent basis (i.e. setting half the house back for 8 hours would produce an $X$ of $1 / 2 \times 1 / 3$ or $1 / 6)$, and $T$ is the temperature difference between setback and normal setpoint. If all results were perfectly consistent, if no differences in thermal relaxation times were present, and if average indoor-outdoor temperature differences were the same, the $E$ values for all predictions and experiments would be the same. 
Table 1. Comparison of Predicted and Measured Energy Savings from Night Setback

\begin{tabular}{|c|c|c|c|c|c|}
\hline $\begin{array}{l}\text { Source, } \\
\text { Location (state) } \\
\text { and } \\
\text { Degree (F) Days }\end{array}$ & $\begin{array}{l}\text { Predic- } \\
\text { tion or } \\
\text { Exper- } \\
\text { iment? }\end{array}$ & $\begin{array}{l}\text { Fraction } \\
\text { of Day } \\
\text { Setback } \\
\text { (Whole- } \\
\text { House } \\
\text { Equiv.) }\end{array}$ & $\begin{array}{l}\text { Setback } \\
\text { Temp- } \\
\text { erature } \\
\text { Differ- } \\
\text { ence } \\
\text { (F) }\end{array}$ & $\begin{array}{l}\text { Percent } \\
\text { Energy } \\
\text { Savings }\end{array}$ & $\begin{array}{l}\text { Figre } \\
\text { of } \\
\text { Effec- } \\
\text { tive- } \\
\text { ness } \\
\left(F^{-1}\right)\end{array}$ \\
\hline $\begin{array}{l}\text { Nephew et al. } 1985 \\
T N-3500\end{array}$ & $\mathbf{P}$ & 0.3 & 10 & 12 & 4.0 \\
\hline $\begin{array}{l}\text { Andrews and } \\
\text { Murray 1987a } \\
\text { PA-5900 } \\
\text { NY }-6900\end{array}$ & $\mathbf{P}$ & 0.3 & 10 & 14 & 4.7 \\
\hline $\begin{array}{l}\text { Griffith } 1985 \\
\mathrm{NJ}-5000\end{array}$ & $E / P$ & 0.3 & 10.8 & 7.6 & 2.3 \\
\hline $\begin{array}{l}\text { Jakob et al. } 1986 \\
\text { PA-5900 }\end{array}$ & $E / P$ & 0.3 & 10 & 14.5 & 4.8 \\
\hline $\begin{array}{l}\text { Leslie and } \\
\text { Kazmer } 1989 \\
\text { IL-6500 }\end{array}$ & $\mathbf{E}$ & 0.3 & 12 & 15 & 4.2 \\
\hline $\begin{array}{l}\text { Flanigan } 1986 \\
\text { OH-5700 [See Note] }\end{array}$ & $\mathbf{E}$ & 0.5 & 12 & 19 & 3.2 \\
\hline
\end{tabular}

Note: Flanigan (1986) set half the house back all the time, so that this differed from night setback.

The average of these $E$ values is 3.9 , with a sample standard deviation of 1.0. Using these values as a benchmark, we may say that current results predict that a $10 \mathrm{~F}$ night setback for 8 hours can be expected to produce energy savings of $13 \pm 3 \%$, at least for locations with between 5000 and 7000 degree days.

Experimental Results--Zoning

Moving on from night setback to experiments that involved actual zoning strategies, we find two field experiments, one in Chicago and one in Maryland, that provide significant data on the energy consequences of zoning. Both these projects were funded by the Gas Research Institute.

A zoned House in Chicago. A study of zoning in a one-story house located in Chicago (Leslie et al. 1988, Leslie and Kazmer 1989) produced mixed results as far as energy savings were concerned. For each series of tests, seasonal energy consumption 
was determined by correlating daily energy consumption with average daily outdoor temperature, for the period of the test, and then annualizing to a full heating season using historical bin weather data.

The system tested was a modulating system that included thermostats, dampers, actuators, a variable-capacity burner, and a variable-speed blower. In view of Modera (1990), it is important to note that return-duct dampers were used (Leslie et al. 1988, p. 2-8). For setback without zoning, the single setpoint was reduced from $72 \mathrm{~F}$ to $60 \mathrm{~F}$ for 8 nighttime hours. For zoning tests, some areas of the house were set back during the day.

Several tests were performed, some of which are difficult to interpret as far as energy savings are concerned because the basement was brought up to the setpoint for part of the day with zoning, whereas it was allowed to float at a lower temperature in the single-zone tests. However, one zoning test in which the basement was not intentionally heated differed from single-zone night setback in that the bedrooms were set back for 10 daytime hours. During this test, the basement floated $-5 \mathrm{~F}$ lower than in the single-zone test (Leslie et al. 1988, p. 3-8 and p. C-56). Because of the lower zone temperatures in this test, the expectation was that there would be significant energy savings. However, the annualized energy consumption for the zoned case was only $1 \%$ less than in the single-zone case. The authors (Leslie and Kazmer 1989, p. 906) point out that the zoned system consumed more energy during moderate weather but less during very cold weather.

To explain this they proposed a specific mechanism that involved the zoned system incurring added duct losses during mild weather that were not incurred during severe weather. During coldweather operation, the central thermostat was usually calling for heat (in the single-zone case) at the time when, in the zoned case, the bedrooms were to recover from setback. Thus it was suggested that the zoning strategy incurs relatively little additional duct loss relative to the single-zone case during severe weather conditions. In mild weather, however, significant duct losses are incurred in bringing the bedrooms up from setback, and this is to be compared with the single-zone case in which the thermostat was not calling for heat at that time (and hence no duct losses were incurred). This type of plausible explanation, like that of Levins (1989), could be explored through simulations. It is mentioned here mainly to emphasize that there are subtleties in zoning that need to be elucidated before reliable design guidelines can be developed. One implication that can be carried away from this experiment is that the location of ductwork in an uninsulated basement was an important factor in the zoned system's inability to save energy.

A Test House in Maryland. Two reports (Oppenheim 1991, Oppenheim 1992) on zoning tests in a research house in Prince Georges County, Maryland, provided significant insights in the cooling and heating modes, respectively. The house is one and 
one-half stories with a total living area of 2,225 $\mathrm{ft}^{2}$, and was designed to conform to expected building practices during the 1990's.

For cooling, the house was divided into three zones, and a two-speed condensing unit was used. Regression lines of electricity consumption vs. average outdoor temperature were used to project seasonal energy usages for each of the following four tests conducted during the summer of 1988 :

1. A baseline test with a single control point maintained at $75 \mathrm{~F}$ all day.

2. A three-zone test with the three control points maintained at $75 \mathrm{~F}$ all day, using indoor blower modulation to achieve zoning and humidity control. Blower overrun was used to capture residual cooling in the indoor coil after heat-pump shutdown.

3. A three-zone test with two of the zones set up $10 \mathrm{~F}$ for $15 \mathrm{hr}$ and the remaining zone set up for $9 \mathrm{hr}$ each day. Blower overrun was used as in Test 2 .

4. A test identical to Test 3 except that blower overrun was not used.

The results were that Test 2 used $20 \%$ more energy than Test 1 , while Tests 3 and 4 saved $25 \%$ and $16 \%$ on cooling energy, relative to Test 1 . The conclusion reached was that zoning for better temperature control (same setpoint in all three zones) could result in increased energy use, whereas periodic setups could reverse this picture and save significant amounts of energy. The use of blower overrun was found to result in worthwhile incremental savings on electric power.

It should be noted that in the cooling mode, comparisons were made between the zoned system and a conventional system maintained at constant setpoint 24 hours per day. For households in which the house is unoccupied during the day, comparable or perhaps greater savings might be achieved in a single-zone system by raising the setpoint when no one is at home.

In the heating mode, a modulating furnace was used. In zoning tests, both supply and return dampers were used. Regression lines of daily gas consumption vs. average outdoor temperature were used to project seasonal gas usage for each test. Whole-house or zone setbacks were from $72 \mathrm{~F}$ to $60 \mathrm{~F}$. Three tests were performed:

1. Baseline heating test with no modulation of furnace input rate or blower speed. One control point was located in the living room; this was set back for $8 \mathrm{hr}$ at night.

2. Zoning with a modulating furnace. Three control points. One of these (the living area) was set back for $8 \mathrm{hr}$ at night, while the other two (bedroom areas) were set back for $22 \mathrm{hr}$ each day, 
with only a $2 \mathrm{hr}$ period in the morning when the thermostat was at its normal setpoint.

3. Zoning with a modulating furnace. Three control points. The living area was set back for $8 \mathrm{hr}$ at night, while the bedroom zones were set back for two separate periods of $10 \mathrm{hr}$ and $8 \mathrm{hr}$, with two 2-hr periods each day in which the thermostat was at its normal setpoint. .

The results were as follows. For test 2 , with one setup period in the two bedroom zones, seasonal energy savings of $12 \%$ relative to the baseline were projected on the basis of the test data. For test 3, with two setup periods, energy use was $6 \%$ more than in the baseline tests. The interpretation of these results by the author was that, everything else being equal, zoning resulted in increased comfort. This is evidenced by a higher balance point for the zoned systems than for the single-zone one. That is, with three thermostats, one can assure that the house is at a more even temperature, but this will increase energy use if portions of the house were too cold with the single thermostat. Then, when a zoning strategy that involves diurnal temperature variations is superimposed on the above, the energy savings may not be enough to overcome the energy deficit imposed by the added comfort. That is, in zoning there is a tradeoff between energy use and comfort, which may result in greater or less energy use than in a single-zone system, depending on circumstance.

The results of the two field tests are summarized in Table 2 .

\section{Significance of Findings}

The findings to date can be summarized as follows. Whole-house night setback in the heating mode is consistently found to save energy, with predicted and experimental values clustering around a $13 \%$ savings for the usual case of $10 \mathrm{~F}, 8-\mathrm{hr}$ setback. For zoning strategies, in which different parts of the house are set to different temperatures for at least part of each day, the picture is much less clear. The variability of results stems from the fact that with more than one control point, the homeowner has the option of using the additional control freedom to purchase some combination of energy savings and improved thermal comfort. At one end of the spectrum are strategies that sacrifice thermal comfort, such as the warm-room concept. Here, energy savings in the $40 \%$ to $50 \%$ range are conceivable. At the other end of the spectrum is a strategy that maintains a 70 or $72 \mathrm{~F}$ setpoint at all control points at all times during the heating season; such a strategy is very likely to use more energy than a single-control-point system set to the same temperature.

Where does this leave us? Recognizing that zoning is difficult and expensive to implement in existing forced-air systems, it may be that efforts to promote it as an energyconservation measure should be abandoned. Where zoning is adopted in existing housing as a means of enhancing thermal comfort, guidelines should be developed to make sure that the system is as 
efficient as possible, consistent with the occupants' needs. These guidelines should include the following:

- Any zoned forced-air system should have operable dampers on both the supply and return lines.

Table 2. Energy Savings Found in Field Experiments on Zoning

\begin{tabular}{|c|c|c|c|}
\hline Source & Location & Heat/Cool & Results \\
\hline $\begin{array}{l}\text { Leslie and } \\
\text { Kazmer } 1989\end{array}$ & Chicago & H & $\begin{array}{l}\text { Zoning with daytime setback } \\
\text { of bedroom area and whole- } \\
\text { house night setback saved } \\
\text { 1f relative to whole-house } \\
\text { night setback alone. }\end{array}$ \\
\hline Oppenheim 1991 & Maryland & C & $\begin{array}{l}\text { A three-zone test with con- } \\
\text { stant setpoints used } 20 \% \\
\text { more energy than a baseline } \\
\text { test with } 1 \text { control point. } \\
\text { Periodic } 10 \text { F setups in all } \\
3 \text { zones resulted in } 16-25 \% \\
\text { savings relative to base- } \\
\text { line. }\end{array}$ \\
\hline Oppenheim 1992 & Maryland & $\mathrm{H}$ & $\begin{array}{l}\text { Baseline test with night } \\
\text { setback. Setbacks for } \\
\text { three zones of } 8,22 \text {, and } \\
22 \text { hours saved } 12 \% \text {. Adding } \\
\text { one additional 2-hr period } \\
\text { of normal setpoint to the } \\
\text { second and third zones } \\
\text { caused energy use to exceed } \\
\text { baseline by } 6 \% \text {. }\end{array}$ \\
\hline
\end{tabular}

- Care should be taken that the zoned system does not produce increased pressures in ducts located outside the conditoned space. Modulating furnaces and fans should be used unless a design that overcomes the need for these has been proven.

- The control strategy should take advantage of all opportunities for temperature setbacks in zones, consistent with the thermal comfort needs of the occupants.

With respect to new housing, a factor that argues against zoning strategies that use diurnal temperature variation is the fact that as insulation levels increase in building envelopes, thermal relaxation times also increase. Whereas a conventional house may have a relaxation time of -24 hours, in superinsulated houses relaxation times of $\sim 100$ hours have been reported (Hagan and Jones 1983, p. 27). This will reduce the percent energy savings for the reasons discussed by Griffith (1985). Moreover, because 
the advanced house is more efficient, the reduced percentage is multiplied by a smaller base to obtain the energy savings in Btu or kWh.

Despite this effect, however, there are some situations in which zoning may make sense even in new housing with good thermal envelopes:

- Very large houses.

- Zoning to compensate for time-varying solar gains received through the south-facing windows in a passive solar house.

- Zoning strategies in which a portion of the house is held permanently at a set-back temperature.

- Zoning strategies that permit shedding part of the heat-pump or air-conditioner load during the utility's peak-load period.

- Unconventional concepts such as the previously mentioned use of distributed backup heaters with heat pumps (Andrews 1986) or the uise of radiant heating to provide thermal comfort in occupied spaces in a house whose air temperature is kept at a low value.

\section{References}

Andrews, J.W. 1986. Zoned Backup in Electric-Powered Heat-Pump Systems: A Way to Conserve Energy and Reduce Utility Peak Loads. BNL 38793 .

Andrews, J.W. and J.G. Murray. 1987a. Proper Furnace sizing: the Key to Residential Zoning. BNL-39544, March 1987.

Andrews, J.W. and J.G. Murray. 1987b. Strategies for Energy Conservation Through Residential Zoning and Reduction of Duct Losses. BNL-52104, July 1987.

BNL 1986. Thermal Distribution Program Plan. Brookhaven National Laboratory Report BNL 52105.

Flanigan, L.J. 1986. A Brief Field study of Multizone Heating of Single- Family Homes. Draft Report. Battelle Columbus Division, 505 King Avenue, Columbus Ohio.

Griffith, J.E. 1985. Determination of Thermal Time Constants in Residential Housing. ASHRAE Trans., Vol,. 91, Pt. 2.

Hagan, D.A. and Jones, R.F. Case Study of the Blouin Superinsulated House. Brookhaven National Laboratory, BNL 51732.

Hedrick, R.L.; Witte, M.J.; Leslie, N.P.; and Bassett, W.W. 1992. Furnace Sizing Criteria for Energy-Efficient Setback Strategies. ASHRAE Trans., Vol. 98, pt. 1. 
Jakob, F.E.; Locklin, D.W.; Fischer, R.D.; Flanigan, L.J.; and Cudnik, R.A. 1986. SP-43 Evaluation of System options for Residential Forced-Air Heating. ASHRAE Trans., Vol. 92, Pt. 2

Kensill, F. 1983. Briefing Paper on the Warm Room Project. Institute for Human Development, Philadelphia, PA. DOE/CE/23861-T1.

Levins, W.P. 1989. Measured Effects of zoning in single-Family Houses. Proc. Conf. on Thermal Performance of the Exterior Envelopes of Buildings IV, CONF-891202-4.

Leslie, N.P.; Carrington, J.S.; Ghassan, P.G.; and Hedrick, R.L. 1988. Conventional Research House zoned Heating Test Results--Topical Report, January 1987-March 1988. GRI 89/0115.

Leslie, N.P. and Kazmer, K.C. 1989. Performance of a Residential Zoned Heating System in an Unoccupied Research House. ASHRAE Trans., Vol. 95, Pt. 1, p. 903.

Modera, M.P. Zone Conditioning in California Residences. 1990. Lawrence Berkeley Laboratory, LBL-30475.

Nephew, E.A. and Moyers, J.C. 1985. Scoping Evaluation of Potential Benefits of Zoning with Residential space-Conditioning Systems. Proc. DOE/ORNL Heat Pump Conference, CONF-841231, pp. 69-73.

Oppenheim, R. 1991. Energy Implications of Blower overrun strategies for a zoned Residential Forced-Air system. ASHRAE Trans., Vol. 97, Pt. 2 .

Oppenheim, R. 1992. Energy-Saving Potential of a Zoned Forced-Air Heating system. ASHRAE Trans., Vol. 98, Pt. 1.

Wagner, B.S. and Diamond, R.C. Keeping Warm: Findings from the Kansas City Warm Room Retrofit Project. Proc. ACEEE 1986 Summer Study on Energy Efficiency in Buildings, Santa Cruz, CA, August 1723, 1986 . 

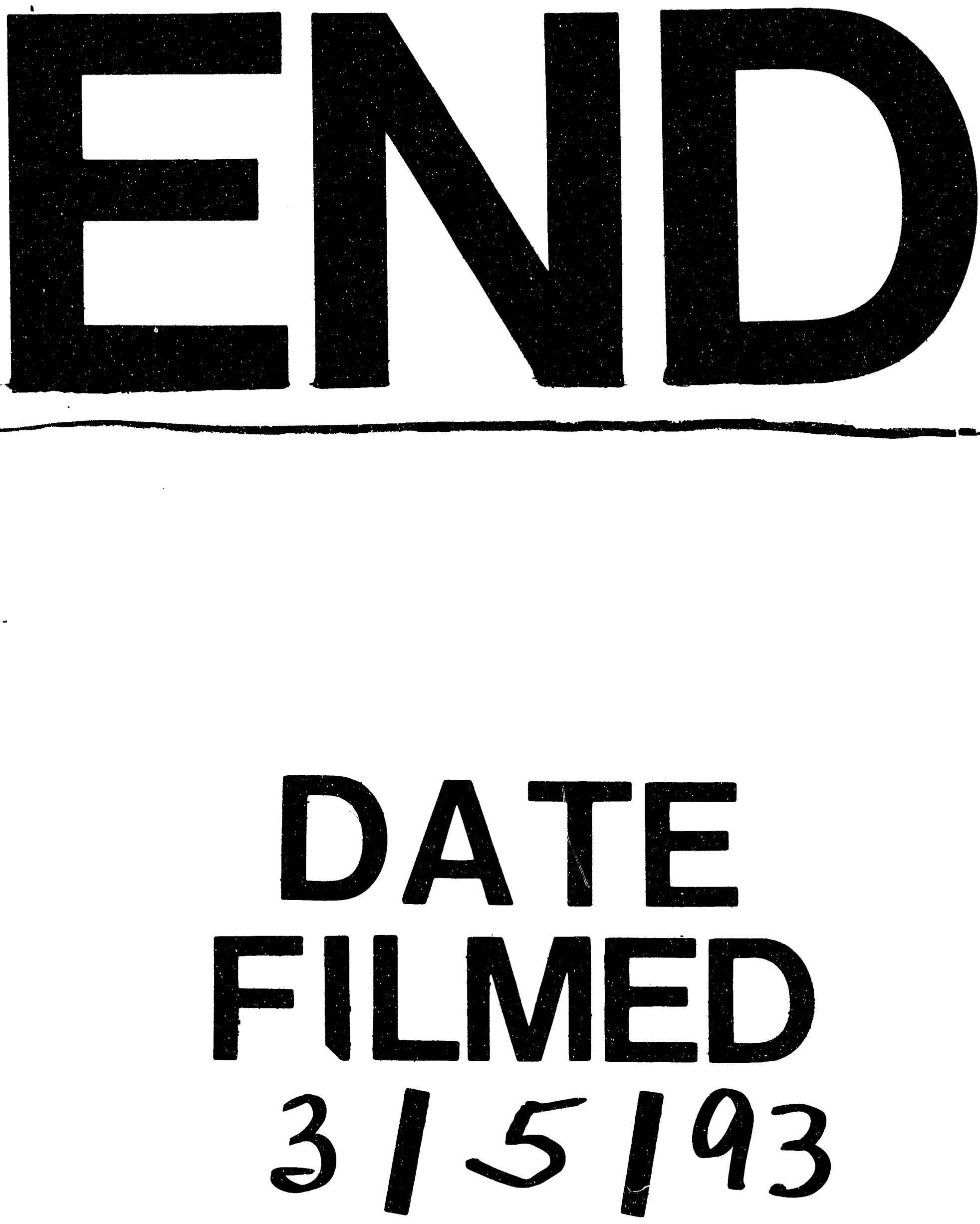
